\author{
H. Vasylyeva ${ }^{1}$, I. Mironyuk ${ }^{2}$, I. Mykytyn ${ }^{2}$, M. Strilchuk ${ }^{3}$, I. Maliuk ${ }^{3}$, V. Tryshyn ${ }^{3}$, \\ Kh.Savka ${ }^{2}$
}

\title{
Application of Titanium Dioxide for Zirconium Ions Adsorption and Separation from a Multicomponent Mixture
}

\author{
${ }^{1}$ Uzhgorod National University, Uzhgorod, Ukraine, h.v.vasylyeva@hotmail.com \\ ${ }^{2}$ Vasyl Stefanyk Precarpathian National University, Ivano-Frankivsk, Ukraine, myrif555@gmail.com \\ ${ }^{3}$ NAS of Ukraine Institute for Nuclear Research, Laboratory of Nuclear Forensics, Kyiv, Ukraine myst@ kinr.kiev.ua
}

This work studies the adsorption of zirconium ions by the mesoporous titanium dioxide and by sodiummodified mesoporous titanium dioxide. Experimental maximal adsorption values of zirconium ions by $\mathrm{H}_{-} \mathrm{TiO}_{2}$ and $\mathrm{Na}-\mathrm{TiO}_{2}$ were found to be $64 \mathrm{mg} / \mathrm{g}$ and $109.5 \mathrm{mg} / \mathrm{g}$ respectively. This process depends on the interaction time, the equilibrium concentration of zirconium ions, and the acidity of the solution. Adsorption kinetics fit well into the diffusion kinetic model and indicate several stages of zirconium ions adsorption. Equilibrium adsorption of zirconium ions is well described by Langmuir's adsorption theory for both adsorbents. The results obtained by inductively coupled plasma mass spectrometry showed that the investigated adsorbent selectively adsorb zirconium ions from the mixture with strontium and yttrium ions in the range of solution $\mathrm{pH}=0-1$. The percentage of maximum extraction of zirconium ions is $86.61 \%$ for $\mathrm{H}-\mathrm{TiO}_{2}$ and $94.11 \%$ for $\mathrm{Na}-\mathrm{TiO}_{2}$. This fact is extremely valuable for nuclear forensics or the determination of ${ }^{90} \mathrm{Sr}$ in low activity background samples.

Keywords: mesoporous $\mathrm{TiO}_{2}$, zirconium ions, adsorption, separation, ICP-MS.

Received 16 July 2021; Accepted 15 August 2021.

\section{Introduction}

The relevance of studies of the adsorption of zirconium ions from aqueous solutions and its selective separation from strontium and yttrium can be explained by multiple factors. One of them is the determination of the low activity of ${ }^{90} \mathrm{Sr}$ in environmental samples. Radioactive ${ }^{90} \mathrm{Sr}$ is a very harmful beta-emitter that accumulates in bones or fish scales [1] and may, significantly harm living organisms in which it accumulates due to the long halflife. Therefore, the maximum allowable levels of ${ }^{90} \mathrm{Sr}$ in the environment are extremely low [2], and their analysis is very difficult to perform. ${ }^{90} \mathrm{Sr}$ is a pure beta-emitter. Gamma spectrometry is unable to determine the amount of ${ }^{90} \mathrm{Sr}$ because it does not produce gamma lines. Its daughter nuclide ${ }^{90} \mathrm{Y}$ also does not emit gamma rays. ${ }^{90} \mathrm{Y}$ $\beta$ - particles have higher maximum energy than $\beta$ - particles of ${ }^{90} \mathrm{Sr}$ (2.281 MeV versus $0.546 \mathrm{MeV}$, respectively) and completely shield strontium. The amount of ${ }^{90} \mathrm{Sr}$ can be approximately determined based on Vavilov-Cherenkov radiation generated by yttrium $\beta$ - particles [3]. Another technique of environmental ${ }^{90} \mathrm{Sr}$ measurement is the separation of ${ }^{90} \mathrm{Sr}$ from yttrium by the oxalate precipitation and subsequent determination of ${ }^{90} \mathrm{Sr}$ amount based on the freshly formed daughter ${ }^{90} \mathrm{Y}$. This technique is used in the determination of the amount of ${ }^{90} \mathrm{Sr}$ in aquatic ecosystems of the Chornobyl Exclusion Zone [1]. However, the accuracy of the oxalate technique is not very high and does not allow determining ${ }^{90} \mathrm{Sr}$ in low-level environmental samples. In this case, inductively coupled plasma mass spectrometry (ICP-MS) may be the only method of ${ }^{90} \mathrm{Sr}$ analysis. Several leading laboratories worldwide [4-6] use this method to analyze ${ }^{90} \mathrm{Sr}$ in the environment. The effectiveness of the ICP-MS method compared to other highly sensitive modern methods is presented in fig. 1.

This method of analysis is very sensitive (Fig. 1), but it diagnoses ${ }^{90} \mathrm{Sr},{ }^{90} \mathrm{Y}$, and ${ }^{90} \mathrm{Zr}$ as a single peak at the mass 
of 90amu. The isotopes of ${ }^{90} \mathrm{Sr},{ }^{90} \mathrm{Y}$, and ${ }^{90} \mathrm{Zr}$

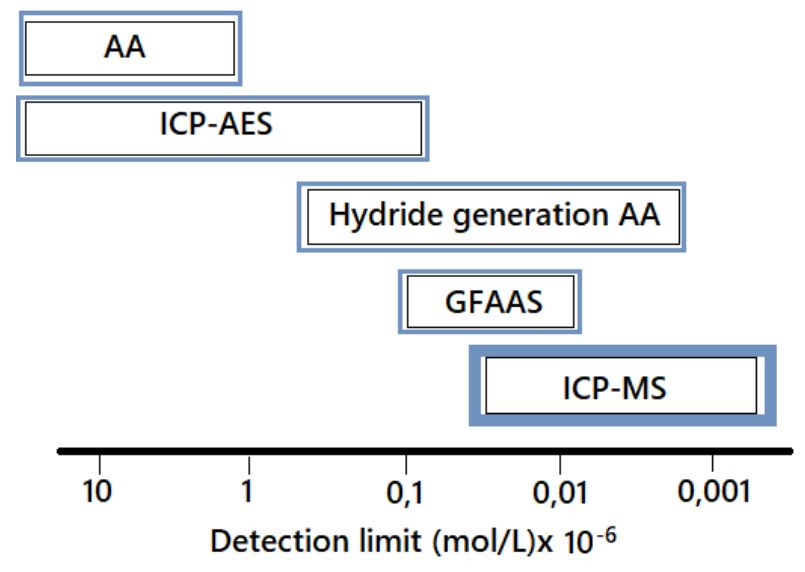

Fig. 1. Detection limits for common elemental techniques: AA - atomic absorption; ICP-AES - inductively coupled plasma atomic emission spectroscopy; GFAAS - graphite furnace atomic absorption; ICP-MS - inductively coupled plasma mass spectrometry (adapted from ref. [4]).

are spectroscopic interferences and overlap each other [46]. ${ }^{90} \mathrm{Zr}$, the "granddaughter" of ${ }^{90} \mathrm{Sr}$, hurts the mass spectrometry of ${ }^{90} \mathrm{Sr}$ samples, as described in [5]. Therefore, it is necessary to separate zirconium and strontium cations.

Nuclear forensic analysis is another application of zirconium adsorption and chemical separation from ${ }^{90} \mathrm{Sr}$ and ${ }^{90} \mathrm{Y}$ in combination with the ICP-MS analysis [7]. The isotopic ratio, measured using ICP-MS, serves as a radio chronometer and can be used to determine the date of fabrication of a ${ }^{90} \mathrm{Sr}-{ }^{90} \mathrm{Y}$ radioactive source. The half-life of ${ }^{90} \mathrm{Y}$ is much shorter (64 hours) than that of ${ }^{90} \mathrm{Sr}(28.8$ years). On elapse of time equal to several half-lives of yttrium, the amount of ${ }^{90} \mathrm{Y}$ becomes constant [8]. Therefore, for nuclear forensics, the important parameters are the number of ${ }^{90} \mathrm{Sr}$ and its "granddaughter" ${ }^{90} \mathrm{Zr}$ nuclei, i. e., the ${ }^{90} \mathrm{Zr} /{ }^{90} \mathrm{Sr}$ ratio, thus methods of chemical separation of these elements become the main direction of scientific research in this field.

Adsorbents based on mesoporous $\mathrm{TiO}_{2}$ showed high adsorption activity toward many cations, such as strontium, barium, zinc, cobalt, and yttrium [9-15]. The uniqueness of the properties of adsorbents based on mesoporous $\mathrm{TiO}_{2}$ is due to the developed surface area and a large number of adsorption centers on it in combination with the predominantly crystalline structure of $\mathrm{TiO}_{2}$. These adsorbents are resistant to aggressive environments and thermally stable. The resistance of mesoporous $\mathrm{TiO}_{2}$ to the action of acids is a very valuable characteristic, as it greatly simplifies the subsequent mass spectrometry of the studied solutions. The introduction of sodium cations into the structure of mesoporous $\mathrm{TiO}_{2}$ leads to functional changes in the surface (for example, an increase in the number of active adsorption sites or shift of the point of zero charges), increasing the adsorption capacity of $\mathrm{Na}$ $\mathrm{TiO}_{2}$ compared to $\mathrm{H}-\mathrm{TiO}_{2}$ relative to heavy metal cations [12]. While the general laws of strontium ion adsorption process by adsorbents based on titanium dioxide are well studied, no surveys have been conducted of the adsorption of zirconium ions by these adsorbents yet.

This work will study the adsorption of zirconium ions by $\mathrm{H}-\mathrm{TiO}_{2}$ and $\mathrm{Na}-\mathrm{TiO}_{2}$, as well as the possibility of separation of ${ }^{90} \mathrm{Sr}$ and ${ }^{90} \mathrm{Zr}$ isotopes by investigated adsorbents for subsequent analysis using inductively coupled plasma mass spectrometry.

\section{Experimental Techniques}

1.1. Synthesis of $\mathrm{H}-\mathrm{TiO}_{2}$ and $\mathrm{Na}-\mathrm{TiO}_{2}$ adsorbents

Experimental samples of anatase modification titanium dioxide with protonated and sodium-modified surface were obtained by sol-gel method, using a solution of titanium aqua complex $\left[\mathrm{Ti}\left(\mathrm{OH}_{2}\right)_{6}\right]^{3+} \cdot 3 \mathrm{Cl}^{-}$as a precursor [12]. The $0,1 \mathrm{M}$ solution of titanium precursor was heated at $60{ }^{\circ} \mathrm{C}$ for 60 minutes to prepare titanium dioxide with a protonated surface $\left(\mathrm{H}-\mathrm{TiO}_{2}\right)$. Globular particles of $\mathrm{TiO}_{2}$ with a diameter of $4-5 \mathrm{~nm}$ were formed in the reaction medium, due to the hydrolysis of the precursor, and condensation of the molecules $\mathrm{Ti}(\mathrm{OH})_{4} \cdot 2 \mathrm{H}_{2} \mathrm{O}$. The $10 \%$ $\mathrm{NaOH}$ solution was added dropwise to the dispersion to deoxidize the resulting product. At $\mathrm{pH} \sim 5.3$ the dispersion thickened rapidly because of gel formation. The hydrogel with a $\mathrm{pH}$ of $\sim 7.0$ was washed with distilled water from the adsorbed impurities of $\mathrm{Na}^{+}, \mathrm{Cl}^{-}$ions. Then, it was dried for 4 hours, at a temperature of $140^{\circ} \mathrm{C}$.

Titanium dioxide with a sodium surface was obtained by contacting globular $\mathrm{TiO}_{2}$ particles with $10 \% \mathrm{NaOH}$ solution. The $\mathrm{TiO}_{2}$ dispersion was kept in an alkali medium ( $\mathrm{pH} \sim 12)$ for 3 hours at room temperature, then the dispersion was washed with distilled water. Washing and decantation of the dispersion were repeated at least 5 times, and after establishing the $\mathrm{pH} \sim 7$, it was dried at a temperature of $140{ }^{\circ} \mathrm{C}$. The main textural characteristics of the adsorbents are shown in Table 1.

\subsection{Batch adsorption studies}

Recommendations for the separation of elements can be made after studying the general patterns of the process of adsorption of the studied elements. Studies of the adsorption capacity of $\mathrm{H}-\mathrm{TiO}_{2}$ and $\mathrm{Na}-\mathrm{TiO}_{2}$ toward zirconium cations were performed under batch conditions. The weight of the adsorbent was $50 \mathrm{mg}$, and the volume of the $\mathrm{ZrOCl}_{2}$ aqueous solution was $5 \mathrm{ml}$. The influence of time interaction, the equilibrium concentration of the zirconium ions, and the acidity of the solution was investigated. Initial and residual concentrations of

Table 1

The textural characteristics of investigated samples, according to [12]

\begin{tabular}{|c|c|c|c|c|c|c|c|}
\hline Sample & $\begin{array}{c}\mathrm{S}_{\mathrm{BET}} \\
\left(\mathrm{m}^{2} \mathrm{~g}^{-1}\right)\end{array}$ & $\begin{array}{c}\mathrm{S}_{\text {micro }} \\
\left(\mathrm{m}^{2} \mathrm{~g}^{-1}\right)\end{array}$ & $\begin{array}{c}\mathrm{S}_{\text {meso }}, \\
\left(\mathrm{m}^{2} \mathrm{~g}^{-1}\right)\end{array}$ & $\begin{array}{c}\mathrm{V}_{\mathrm{p}}, \\
\left(\mathrm{cm}^{3} \mathrm{~g}^{-1}\right)\end{array}$ & $\begin{array}{c}\mathrm{V}_{\text {micro }} \\
\left(\mathrm{cm}^{3} \mathrm{~g}^{-1}\right)\end{array}$ & $\begin{array}{c}\mathrm{V}_{\text {meso }} \\
\left(\mathrm{cm}^{3} \mathrm{~g}^{-1}\right)\end{array}$ & $\mathbf{p H}$ pzc \\
\hline $\mathrm{H}_{-}-\mathrm{TiO}_{2}$ & 349 & 129 & 230 & 0.191 & 0.061 & 0.130 & 5.35 \\
\hline $\mathrm{Na}_{2} \mathrm{TiO}_{2}$ & 239 & 100 & 139 & 0.152 & 0.054 & 0.098 & 9.42 \\
\hline
\end{tabular}


zirconium ions were determined using direct complexometric titration in a strongly acidic medium with Xylenol Orange as an indicator [16]. Adsorption values were calculated using (eq.1) as follows:

$$
q_{e}=\frac{\left[\left(C_{o}-C_{e}\right) V\right]}{m},
$$

where $\mathrm{q}_{\mathrm{e}}-$ is the amount of adsorbate uptake, $\mathrm{mg} / \mathrm{g} ; \mathrm{C}_{\mathrm{o}}$ and $\mathrm{C}_{\mathrm{e}}-$ are initial and residual concentrations of adsorbate, $\mathrm{mg} / \mathrm{L} ; \mathrm{V}$ - is solution volume, $\mathrm{L} ; \mathrm{m}$ - is mass of adsorbent, $\mathrm{g}$ [17].

The influence of solution acidity on zirconium cations adsorption by investigated adsorbents was studied under the same conditions, however, the volume of the solution was $10 \mathrm{ml}\left(5 \mathrm{ml}\right.$ of $\mathrm{ZrOCl}_{2}$ solution and $5 \mathrm{ml}$ of the medium) and the mass of the adsorbent remained unchanged.

The most commons adsorption kinetic models were applied to experimental data: kinetic models based on pseudo-first, pseudo-second-order equations; Elovich and diffusion kinetic models. However, special attention was paid to the Elovich model $\left(\mathrm{q}_{\mathrm{t}}=f(\ln \mathrm{t})\right)$ and the diffusion kinetic model $\left(\mathrm{q}_{\mathrm{t}}=f\left(\mathrm{t}^{0.5}\right)\right)$, as they allow predicting the mechanism of adsorption: mainly physical (diffusion model), or chemisorption (Elovich model) [18-23]. Langmuir and Freundlich's adsorption theories were used to analyze the equilibrium adsorption. The equations of these theories (2) and (3) are given below:

$$
\begin{aligned}
& q_{e}=\frac{A_{\max } K C_{e}}{1+K C_{e}}, \\
& q_{e}=K_{f} \times C_{e}^{n},
\end{aligned}
$$

where, $A_{\max }(\mathrm{mg} / \mathrm{g})$ - maximum adsorption value, which corresponds of fill in the whole adsorption centers; $K_{L}$ (L/mg) - Langmuir constant; $\mathrm{C}_{\mathrm{e}}(\mathrm{mg} / \mathrm{L})$ - adsorbate equilibrium concentration; $\mathrm{q}_{\mathrm{e}}(\mathrm{mg} / \mathrm{g})$ - quantities of adsorbate uptake at equilibrium; $\mathrm{K}_{\mathrm{f}}-$ Freundlich constant, $\frac{m g / g}{\left(\frac{m g}{L}\right) n} ;$ n- Freundlich intencity parameter.

Separation factor $\alpha_{\mathrm{Sr}, \mathrm{Zr}}$ of strontium and zirconium was calculated according to [7]:

$$
\alpha_{S r, Z r}=\frac{\text { Intensity }[C p s] 88-S r}{\text { Intensity }[C p s] 90-Z r}
$$

where Intensity in [count per second] was experimentally measured value by ICP-MS of corresponding isotopes after adsorption.

Nonlinear approximation of experimental results was processed in the "Solver add-in" to Microsoft Office Excel. The chi-squared test is highly recommended for the nonlinear method to confirm the best fitting isotherm for a given adsorption system. High $\chi^{2}$ indicates high divergence between the experiment and the model. The chi-square value $\chi^{2}$ and coefficient of determination $\mathrm{R}^{2}$ were calculated using equations (5) and (6). In general, the recommendations from the publication [20] were used in the analysis of experimental adsorption results.

$$
R^{2}=1-\frac{\sum\left(q_{e, \text { exp }},-q_{e, \text { calc }}\right)^{2}}{\sum\left(q_{e, \text { exp }}-q_{e, \text { mean }}\right)^{2}}
$$

$$
\chi^{2}=\sum \frac{\left(q_{e, e x p}-q_{e, c a l c}\right)^{2}}{q_{e, \text { calc }}} .
$$

\subsection{ICP-MS analysis of separation of investigated cations}

The study of the possibility of strontium, yttrium, and zirconium ions separation using the investigated adsorbents was performed under batch conditions. The ${ }^{88} \mathrm{Sr},{ }^{89} \mathrm{Y},{ }^{90,91} \mathrm{Zr}$ isotopes were analyzed by the inductively coupled plasma mass spectrometer (ICP-MS) [4-6] 'Element 2' with argon plasma, located in the Nuclear Forensics laboratory of KINR, Kyiv. The study was performed with a mixture of the high purity standards solutions (High Purity Standards, USA) of the corresponding elements.

The results were measured in the number of [CPS] pulses "count per second" relative to $\mathrm{m} / \mathrm{z}$.

As has been said above, ${ }^{90} \mathrm{Y}$ does not play a significant role in determining the date of fabrication of a ${ }^{90} \mathrm{Sr}-{ }^{90} \mathrm{Y}$ radioactive source. This is due to the fact, that the half-life of ${ }^{90} \mathrm{Y}$ is much shorter (64 hours) than the half-life of ${ }^{90} \mathrm{Sr}$ (28.8 years) and its amount throughout the life of ${ }^{90} \mathrm{Sr}$ remains constant. This statement can be illustrated by formulas (7) - (9):

$$
\lambda_{2}-\lambda_{1} \cong \lambda_{2}
$$

Where $\lambda_{2},-$ Decay constant of ${ }^{90} \mathrm{Y} ; \lambda_{1},-$ decay constant of ${ }^{90} \mathrm{Sr}$.

The number of daughter nuclei is related to the number of parent nuclei by the equation (7):

$$
\begin{aligned}
N_{Y}= & \frac{\lambda_{1}}{\lambda_{2}-\lambda_{1}} \times N_{S r}\left(e^{-\lambda 1 t}-e^{-\lambda 2 t}\right) \cong \\
& \cong \frac{\lambda_{1}}{\lambda_{2}} N_{S r}\left(1-e^{-\lambda 2 t}\right)
\end{aligned}
$$

After several half-lives, an equilibrium establishes and the amount of $90 \mathrm{Y}$ can be calculated:

$$
N_{Y}=\frac{\lambda_{1}}{\lambda_{2}}\left(N_{S r}\right), \text { or } \frac{N_{Y}}{\left(T_{1 / 2}\right)^{2}}=\frac{N_{S r}}{\left(T_{1 / 2}\right) 1},
$$

$\lambda_{2},\left(T_{\frac{1}{2}}\right) 2$ - Half-life of ${ }^{90} \mathrm{Y}$;

$\lambda_{1}, \mathrm{i}\left(T_{\frac{1}{2}}\right) 1$-- Half-life of ${ }^{90} \mathrm{Sr}$.

Stable ${ }^{89} \mathrm{Y}$, in contrast to ${ }^{90} \mathrm{Y}$, plays a significant role, because it was very often used as a carrier for radioactive ${ }^{90} \mathrm{Sr}$ and ${ }^{90} \mathrm{Y}$. This was because, the separation of ${ }^{90} \mathrm{Sr}$ from a mixture of fission radionuclides, during fabrication of a ${ }^{90} \mathrm{Sr}-{ }^{90} \mathrm{Y}$ radioactive source, was carried out by the reaction of precipitation of strontium and yttrium with oxalates [1]. Stable ${ }^{89} \mathrm{Y}$ in the result ${ }^{90} \mathrm{Sr}-{ }^{90} \mathrm{Y}$ source may be at a high concentration. It can affect the selective adsorption of $\mathrm{Sr}^{2+}$ or $\mathrm{Zr}^{4+}$ because the cations $\mathrm{Y}^{3+}$ are also adsorbed on the surface of titanium dioxide. Therefore, a mixture of isotopes of ${ }^{88} \mathrm{Sr},{ }^{90} \mathrm{Zr},{ }^{91} \mathrm{Zr}$, and ${ }^{89} \mathrm{Y}$ was subjected to the analysis by ICP-MS. A great advantage of ICP-MS is its multi-element capability, which allows multiple elements to be measured simultaneously in a single analysis. However, interferences need to be controlled. Internal standardization is usually employed to 
correct for changes in instrument operating conditions and sample-specific matrix effects. According to recommendations, which were given in publication [5], the internal standard will have a similar mass and ionization potential to the analyte $\left({ }^{88} \mathrm{Sr},{ }^{89} \mathrm{Y},{ }^{90} \mathrm{Zr},{ }^{91} \mathrm{Zr}\right)$. Therefore, ${ }^{103} \mathrm{Rh}$ was chosen, as an internal standard. External calibration of the ICP-MS was performed using calibration Standard A, containing known concentrations of the elements. The error due to the formation of polyatomic ions ${ }^{89} \mathrm{Y}^{1} \mathrm{H}$ in plasma was determined using Standard 1. Standard 1 is a mixture of about $10 \mathrm{ng}{ }^{88} \mathrm{Sr}$ and ${ }^{89} \mathrm{Y}$. Standard solution 2 (Standard 2) was a mixture of ${ }^{88} \mathrm{Sr},{ }^{89} \mathrm{Y},{ }^{90} \mathrm{Zr},{ }^{91} \mathrm{Zr}$, which was divided into 5 equal parts, four of them were mixed with adsorbents, and the fifth was left as a control solution. In addition, Standard 3 was pure $2 \% \mathrm{HNO}_{3}$ 'Optima'.

Adsorption and separation of strontium, yttrium, and zirconium ions were performed in batch conditions for an hour. Mass of adsorbents was $100 \mathrm{mg}$, volume of solutions $-10 \mathrm{ml}$. After adsorption, the adsorbents were separated from the solution by filtration. The slow-filtering paper with dense narrow pores for finest deposits was selected for this purpose. Selective adsorption of zirconium and the possibility of separation of zirconium from strontium and yttrium were evaluated by analyzing the isotopes ${ }^{88} \mathrm{Sr},{ }^{89} \mathrm{Y}$, ${ }^{90} \mathrm{Zr},{ }^{91} \mathrm{Zr}$, and ${ }^{103} \mathrm{Rh}$ by ICP-MS at least three times.

\section{Results and Discussion}

\subsection{Adsorption of zirconium ions by $\mathrm{H}-\mathrm{TiO}_{2}$ and} $\mathrm{Na}-\mathrm{TiO}_{2}$
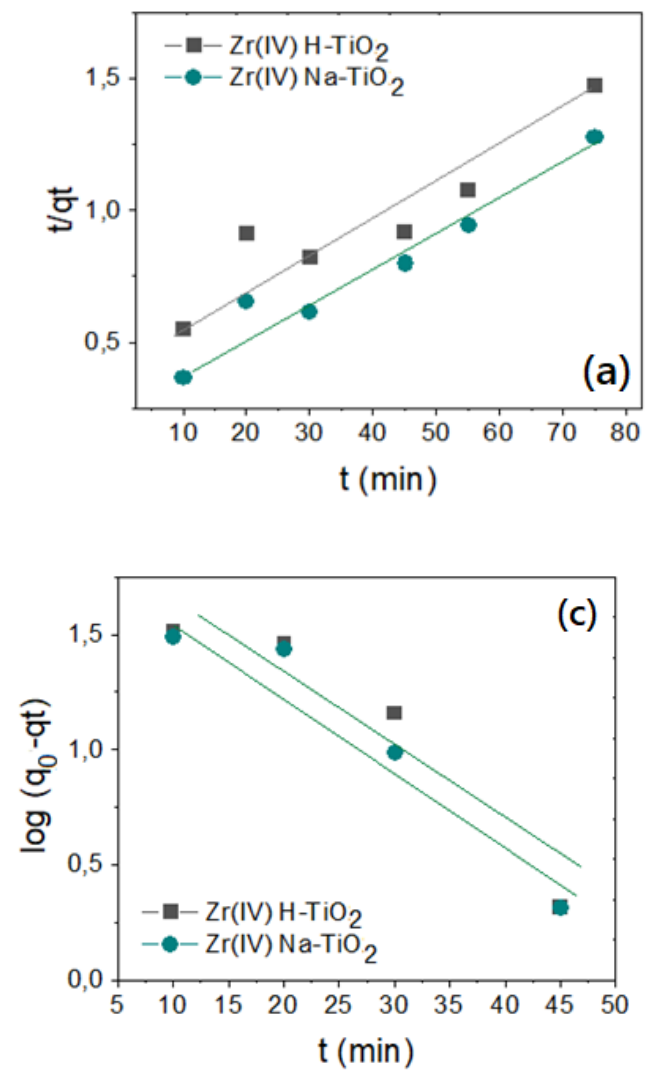

The results of the dependence of the zirconium adsorption values by $\mathrm{H}-\mathrm{TiO}_{2}$ and $\mathrm{Na}-\mathrm{TiO}_{2}$ on agitation time are shown in Fig. 2.

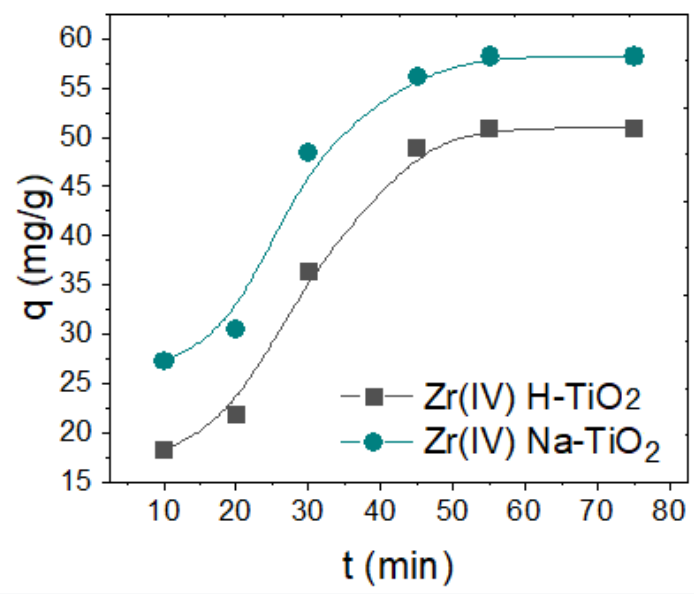

Fig. 2. Dependence of the adsorption values of zirconium ions by $\mathrm{H}-\mathrm{TiO}_{2}$ and $\mathrm{Na}-\mathrm{TiO}_{2}$ on the agitation time.

The results, which are shown in Fig. 3 and Table 2, indicate that the diffusion model best describes the process of adsorption of zirconium ions by the investigated adsorbents. According to the results of the analysis, the zirconium ions adsorption by $\mathrm{H}-\mathrm{TiO}_{2}$ and $\mathrm{Na}-\mathrm{TiO}_{2}$ occurs in several stages: diffusion from solution to the surface of the adsorbents (Step 1 'bulk transport'); diffusion on the adsorbent's surface (Step 2 'film diffusion') and diffusion deep into the pores of the adsorbent (Step 3 'intraparticle diffusion'). The highest diffusion coefficients $\left(\mathrm{k}_{\mathrm{ipd}}\right)$ were
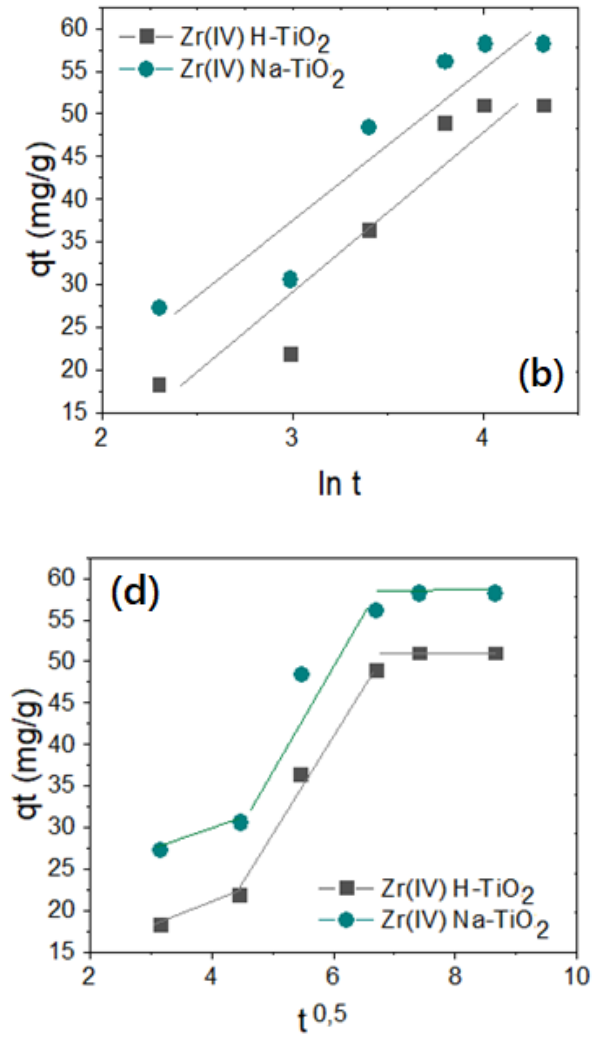

Fig. 3. Application of kinetic models to experimental results of zirconium ions adsorption by $\mathrm{H}-\mathrm{TiO}_{2}$ and Na- $\mathrm{TiO}_{2}$ : (a) Pseudo-second; (b) Elovich; (c) Pseudo-first; (d) Intra-particle diffusion kinetic models. 
Application of kinetic models to experimental results of zirconium ions adsorption by $\mathrm{H}-\mathrm{TiO}_{2}$ and $\mathrm{Na}-\mathrm{TiO}_{2}$

\begin{tabular}{|c|c|c|c|c|}
\hline Model & Adsorbent & Equation & Parameters & $\mathrm{R}^{2}$ \\
\hline \multirow[t]{2}{*}{ Pseudo-first } & $\mathrm{H}-\mathrm{TiO}_{2}$ & $\log \left(\mathrm{q}_{\mathrm{o}}-\mathrm{q}_{\mathrm{t}}\right)=-0.035 \mathrm{t}+2.035$ & $\mathrm{k}_{1}=0.035$ & 0.8952 \\
\hline & $\mathrm{Na}-\mathrm{TiO}_{2}$ & $\log \left(\mathrm{q}_{\mathrm{o}}-\mathrm{q}_{\mathrm{t}}\right)=-0.035 \mathrm{t}+1.98$ & $\mathrm{k}_{1}=0.035$ & 0.9365 \\
\hline \multirow{2}{*}{$\begin{array}{l}\text { Pseudo- } \\
\text { second }\end{array}$} & $\mathrm{H}-\mathrm{TiO}_{2}$ & $\mathrm{t} / \mathrm{q}_{\mathrm{t}}=0.019 \mathrm{t}+0.49$ & $\mathrm{k}_{2}=0.019$ & 0.8664 \\
\hline & $\mathrm{Na}-\mathrm{TiO}_{2}$ & $\mathrm{t} / \mathrm{q}_{\mathrm{t}}=0.0128 \mathrm{t}+0.27$ & $\mathrm{k}_{2}=0.0128$ & 0.9511 \\
\hline \multirow[t]{2}{*}{ Elovich } & $\mathrm{H}-\mathrm{TiO}_{2}$ & $\mathrm{q}_{\mathrm{t}}=19.33 \ln \mathrm{t}-29$ & $\alpha=4.32 ; \beta=0.0517$ & 0.9155 \\
\hline & $\mathrm{Na}-\mathrm{TiO}_{2}$ & $\mathrm{q}_{\mathrm{t}}=18.17 \ln \mathrm{t}-29$ & $\alpha=6.82 ; \beta=0.055$ & 0.902 \\
\hline \multirow{2}{*}{$\begin{array}{l}\text { Difussion } \\
\text { Step } 1\end{array}$} & $\mathrm{H}-\mathrm{TiO}_{2}$ & $\mathrm{q}_{\mathrm{t}}=2.52 \mathrm{t}^{0.5}+19$ & $\mathrm{k}_{\mathrm{ipd}}=2.52 ; \mathrm{C}=19$ & 0.999 \\
\hline & $\mathrm{Na}-\mathrm{TiO}_{2}$ & $\mathrm{q}_{\mathrm{t}}=2.78 \mathrm{t}^{0.5}+9.4$ & $\mathrm{k}_{\mathrm{ipd}}=2.78 ; \mathrm{C}=9.4$ & 0.999 \\
\hline \multirow[t]{2}{*}{ Step 2} & $\mathrm{H}-\mathrm{TiO}_{2}$ & $\mathrm{q}_{\mathrm{t}}=5.14 \mathrm{t}^{0.5}+20.7$ & $\mathrm{k}_{\mathrm{ipd}}=5.14 ; \mathrm{C}=20.7$ & 0.9723 \\
\hline & $\mathrm{Na}-\mathrm{TiO}_{2}$ & $\mathrm{q}_{\mathrm{t}}=7.79 \mathrm{t}^{0.5}-5.47$ & $\mathrm{k}_{\mathrm{ipd}}=7.79$ & 0.9446 \\
\hline \multirow[t]{2}{*}{ Step 3} & $\mathrm{H}-\mathrm{TiO}_{2}$ & $\mathrm{q}_{\mathrm{t}}=0.768 \mathrm{t}^{0.5}+52$ & $\mathrm{k}_{\mathrm{ipd}}=0.768 ; \mathrm{C}=52$ & 0.999 \\
\hline & $\mathrm{Na}-\mathrm{TiO}_{2}$ & $\mathrm{q}_{\mathrm{t}}=0.072 \mathrm{t}^{0.5}+50$ & $\mathrm{k}_{\mathrm{ipd}}=0.072 ; \mathrm{C}=50$ & 0.999 \\
\hline
\end{tabular}

$q_{o}$ and $q_{t}(\mathrm{mg} / \mathrm{g})$ - adsorption capacity at equilibrium and time $t$. respectively; $k_{1}\left(\mathrm{~min}^{-1}\right) . k_{2}\left(g \cdot \mathrm{mg}^{-1} \mathrm{~min}^{-1}\right) \mathrm{rate}$ coefficients of pseudo-first order equation and pseudo-second order equation. $D_{\text {ipd }}\left(\mathrm{mg} / \mathrm{g} \mathrm{min} \mathrm{m}^{0.5}\right)-$ coefficient of intra-particle diffusion; $\beta$ ( $\mathrm{mg} / \mathrm{g})$ - desorption constant. $\alpha$ ( $\mathrm{mg} / \mathrm{g} \mathrm{min})$ - rate coefficients of Elovich equation.

observed during the diffusion of zirconium ions along the surface of $\mathrm{H}-\mathrm{TiO}_{2}$ and $\mathrm{Na}-\mathrm{TiO}_{2}$. The values of the constant $\mathrm{C} \mathrm{mg/g}$ in the equations of the diffusion model are related to the thickness of the boundary layer [20]. The larger value of $\mathrm{C}$ means the greater effect of the thickness of the boundary layer on the adsorption of zirconium ions. When zirconium ions diffuse along the $\mathrm{Na}^{-} \mathrm{TiO}_{2}$ surface, the boundary layer does not affect the adsorption. In all other cases, the values of $\mathrm{C}$ are significant, so the thickness of the boundary layer of the adsorbent surface affects the process of adsorption of zirconium ions from the neutral medium. For the adsorbent $\mathrm{H}-\mathrm{TiO}_{2}$, the value of $\mathrm{C}$ increases in the series Step 1-Step 2-Step 3 and has a value of $19 \mathrm{mg} / \mathrm{g} ; 20.7 \mathrm{mg} / \mathrm{g}$, and $52 \mathrm{mg} / \mathrm{g}$, respectively.

2.2. Equilibrium adsorption of zirconium ions by $\mathrm{H}-\mathrm{TiO}_{2}$ and $\mathrm{Na}-\mathrm{TiO}_{2}$ and influence of solution acidity on the adsorption process

The results of equilibrium studies of zirconium ions adsorption by $\mathrm{H}-\mathrm{TiO}_{2}$ and $\mathrm{Na}-\mathrm{TiO}_{2}$ are shown in Fig. 4 and Fig. 5. The application of the Langmuir and Freundlich theories to the experimental results is given in Table 3.

The experimental isotherms of zirconium ions adsorption by the studied adsorbents are better described by Langmuir's theory than by Freundlich's theory for both adsorbents. However, the divergence between the experimental results and calculated by Langmuir theory $\left(\chi^{2}\right)$ for $\mathrm{Na}-\mathrm{TiO}_{2}$ are higher. The main differences between the experimental values and the theoretically calculated ones for zirconium ions adsorption by the $\mathrm{Na}-\mathrm{TiO}_{2}$ are in the region of low equilibrium concentrations of the adsorbate. This can be explained by the very active surface of the adsorbent. In our opinion, this is the reason for rather high values of $\chi^{2}$. The values of the maximum adsorption of zirconium ions calculated according to Langmuir theory are in good agreement with the experimentally determined ones (Table 3) and are lower than the values of adsorption of strontium ions by the $\mathrm{H}$ $\mathrm{TiO}_{2}$ and $\mathrm{Na}-\mathrm{TiO}_{2}[12]$. The maximum adsorption values

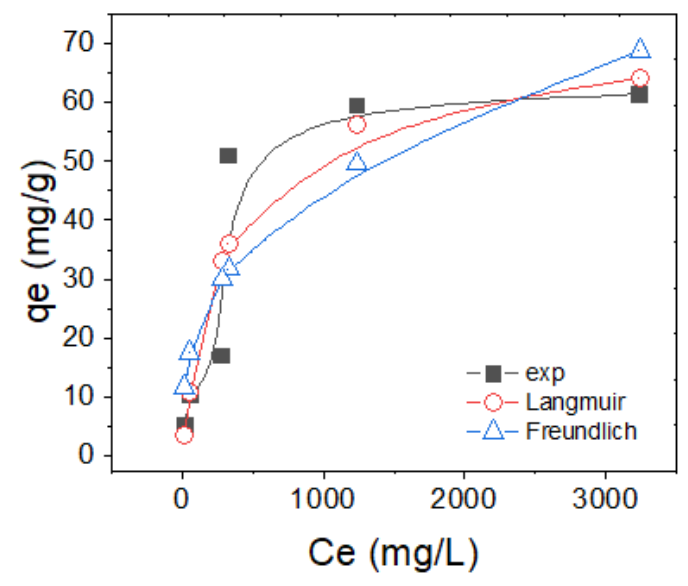

Fig. 4. Isotherm of zirconium ions adsorption by $\mathrm{H}-\mathrm{TiO}_{2}$; nonlinear approximation by Langmuir and Freundlich theories.

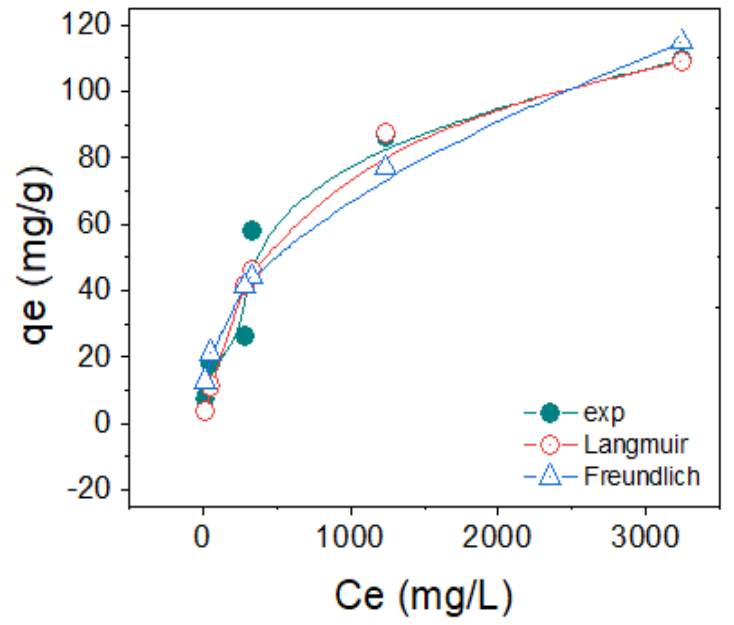

Fig. 5. Isotherm of zirconium ions adsorption by $\mathrm{Na}-\mathrm{TiO}_{2}$; nonlinear approximation by Langmuir and Freundlich theories. 
Table 3

Application of the Langmuir and Freundlich theories to the experimental equilibrium adsorption of zirconium ions by $\mathrm{H}-\mathrm{TiO}_{2}$ and $\mathrm{Na}-\mathrm{TiO}_{2}$

\begin{tabular}{|c|l|c|c|c|c|}
\hline $\begin{array}{c}\text { Adsorption } \\
\text { process }\end{array}$ & Theory & $\begin{array}{c}\text { Parameters of } \\
\text { equation of } \\
\text { corresponding } \\
\text { theory }\end{array}$ & $\begin{array}{c}\text { Calculated } \mathrm{q}_{\max }, \\
\mathrm{mg} / \mathrm{g}\end{array}$ & $\mathrm{R}^{2}$ & $\chi^{2}$ \\
\hline $\begin{array}{c}\mathrm{Zr}^{4+} \text { by } \mathrm{H}-\mathrm{TiO}_{2} \\
\mathrm{q}_{\mathrm{e} \text { exp }}=61.4 \mathrm{mg} / \mathrm{g}\end{array}$ & Langmuir & $\begin{array}{c}\mathrm{K}_{\mathrm{L}}=0.00318 \\
A_{\max }=70.46\end{array}$ & 64.23 & 0.8544 & 15.11 \\
\cline { 2 - 6 } & Freundlich & $\begin{array}{c}\mathrm{K}_{f}=4.458 \\
n=0.338\end{array}$ & 68.73 & 0.7747 & 26.78 \\
\hline $\begin{array}{c}\mathrm{Zr}^{4+} \text { by } \\
\mathrm{Na}-\mathrm{TiO}_{2}\end{array}$ & Langmuir & $\begin{array}{c}\mathrm{K}_{\mathrm{L}}=0.00169 \\
\mathrm{q}_{\mathrm{max}}=128.99\end{array}$ & 109.1 & 0.9166 & 16.17 \\
\cline { 2 - 6 }$=109.5 \mathrm{mg} / \mathrm{g}$ & Freundlich & $\begin{array}{c}\mathrm{K}_{f}=3.893 \\
n=0.4188\end{array}$ & 114.9 & 0.8862 & 14.27 \\
\hline
\end{tabular}

Table 4

Values of self-diffusion coefficients of $\mathrm{Zr}$ (IV) and $\mathrm{Sr}$ (II) ions in aqueous solutions with different $\mathrm{pH}$ according to publication [25]

\begin{tabular}{|c|c|c|c|}
\hline $\mathrm{pH}$ & $\begin{array}{c}\mathrm{Zr}(\mathrm{IV}) \\
\mathrm{D} 10^{-5} \mathrm{~cm}^{2} / \mathrm{s}\end{array}$ & $\mathrm{Zr}(\mathrm{IV})$ radius, $\AA$ & $\begin{array}{c}\mathrm{Sr}(\mathrm{II}) \\
\mathrm{D} 10^{-5} \mathrm{~cm}^{2} / \mathrm{s}\end{array}$ \\
\hline $9 \mathrm{M}$ & $0.3 \pm 0.016$ & 4.8 & $5.58 \pm 0.08$ \\
\hline $6 \mathrm{M}$ & $0.345 \pm 0.005$ & 4.8 & $6.0 \pm 0.13$ \\
\hline $3 \mathrm{M}$ & $0.42 \pm 0.007$ & 4.8 & $6.23 \pm 0.07$ \\
\hline $2 \mathrm{M}$ & $0.46 \pm 0.01$ & 4.8 & \\
\hline $1 \mathrm{M}$ & $0.48 \pm 0.014$ & 4.8 & \\
\hline $0.4 \mathrm{M}$ & $0.488 \pm 0.003$ & 4.8 & \\
\hline $0.1 \mathrm{M}$ & $0.351 \pm 0.006$ & 7.0 & \\
\hline $\mathrm{pH}=2$ & $0.205 \pm 0.011$ & 11 & $7.75 \pm 0.04$ \\
\hline $\mathrm{pH}-2.8$ & $0.137 \pm 0.004$ & 12 & \\
\hline $\mathrm{pH}=4.2$ & $0.056 \pm 0.004$ & 44 & \\
\hline $\mathrm{pH}=7.5$ & $0.05 \pm 0.009$ & 50 & $7.79 \pm 0.1$ \\
\hline $\mathrm{pH}=8.2$ & $0.115 \pm 0.004$ & 21 & \\
\hline $\mathrm{pH}=10.4$ & $0.106 \pm 0.021$ & 23 & \\
\hline $\mathrm{pH}=11.5$ & $0.13 \pm 0.01$ & 19 & $7.58 \pm 0.06$ \\
\hline
\end{tabular}

of the strontium ions in the neutral medium are $78.4 \mathrm{mg} \cdot \mathrm{g}^{-1}$ by $\mathrm{H}^{-\mathrm{TiO}_{2}}$ and $208.4 \mathrm{mg} \cdot \mathrm{g}^{-1}$ by $\mathrm{Na}^{-\mathrm{TiO}_{2}}$ and the maximum adsorption of zirconium ions are 61.4 $\mathrm{mg} \cdot \mathrm{g}^{-1}$ by $\mathrm{H}-\mathrm{TiO}_{2}$ and $109.5 \mathrm{mg} \cdot \mathrm{g}^{-1}$ by $\mathrm{Na}^{-\mathrm{TiO}_{2}}$. The reason for the lower adsorption of zirconium ions compared to strontium ions in aqueous solutions with a neutral $\mathrm{pH}$ may be the high tendency of zirconium cations to hydrolysis [24, 25].

The plot, shown in Fig. 6 indicates that the weakest adsorption of zirconium ions occurs in a neutral medium. The tendency of zirconium cations to hydrolyze [20, 21] determines the large size of hydrolyzed zirconium ions and their low mobility in solution and, accordingly, insignificant adsorption.

The results presented in Fig. 6 are in good agreement with the literature data on the mobility and size of zirconium ions in solution, shown in Table 4. For comparison, the table shows the values of the mobility of strontium cations, as well. The concentration of the corresponding ions was $10^{-5} \mathrm{~mole} / \mathrm{L}$; studies were performed using $\mathrm{HCl}, \mathrm{NH}_{4} \mathrm{OH}$, and 100 -fold excess of electrolyte $\mathrm{NH}_{4} \mathrm{Cl}$.

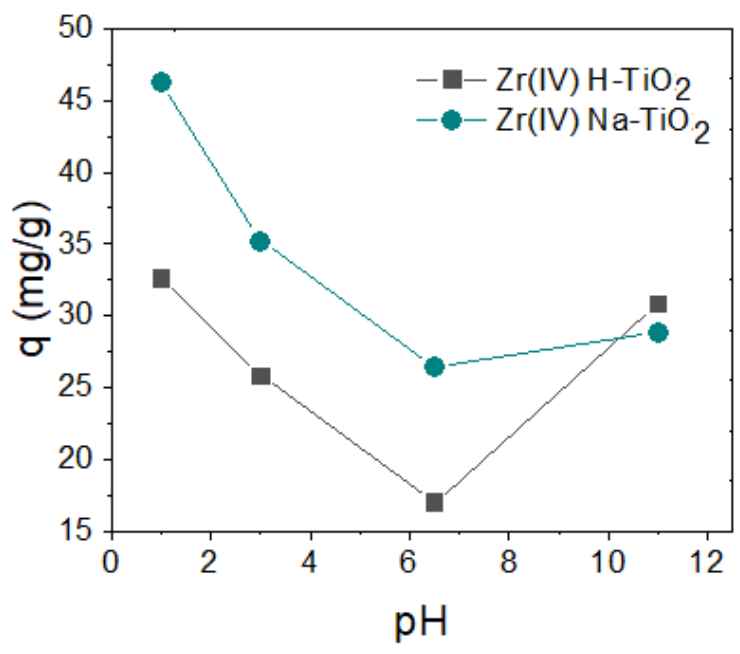

Fig.6. $\mathrm{pH}$ dependence of zirconium ions adsorption by $\mathrm{H}$ $\mathrm{TiO}_{2}$ and $\mathrm{Na}-\mathrm{TiO}_{2}$ 


\subsection{Selective adsorption of zirconium ions from} the mixture

Schematically, the experiment on the adsorption separation of strontium, yttrium, and zirconium ions is shown in Fig. 7.

The results presented in Tables 5 and 5 (a) indicate the selective adsorption of zirconium ions from a mixture of strontium and yttrium ions. This process is illustrated in Figs. 8 (a) and (b). The results in Table 5 (a) indicate that the amount of strontium, yttrium and internal rhodium ions was not changed after interaction with adsorbents. This fact evidences the absence of adsorption of these elements under experimental conditions. Analysis by ICPMS showed that the error due to the formation of ${ }^{89} \mathrm{Y}^{1} \mathrm{H}$ polyatomic ions is 1210 counts per second at a mass of 90amu. In addition, the number of contaminants of ${ }^{88} \mathrm{Sr}$ and ${ }^{90} \mathrm{Zr}$ in the used solvent was recorded. If we take into account all these contributors to the mass peak of 90amu and subtract the background number of counts from ${ }^{90} \mathrm{Zr}$, the percentage of extracted ${ }^{90} \mathrm{Zr}$ will be $86.61 \%$ for $\mathrm{H}$ -
$\mathrm{TiO}_{2}$ and $94.11 \%$ for $\mathrm{Na}-\mathrm{TiO}_{2}$.

Figures 8 (a) and (b) illustrate the selective adsorption of zirconium ions by $\mathrm{H}-\mathrm{TiO}_{2}$ and $\mathrm{Na}-\mathrm{TiO}_{2}$ from nitric acid with HF micro-impurities in the absence of adsorption of strontium and yttrium ions. The amount of strontium ions even slightly increases due to the ${ }^{88} \mathrm{Sr}$ contaminated micro impurities (Fig. 8 (a)).

Selective zirconium ion adsorption is observed in the range of solutions acidity $\mathrm{pH}=0-1$. This range of solution acidities is below the pHpzc of the studied adsorbents (Table 1). The number of adsorption centers ( $\equiv \mathrm{TiO}-)$ able to bind cations is slightly reduced and the surface of $\mathrm{H}$ $\mathrm{TiO}_{2}$ or $\mathrm{Na}-\mathrm{TiO}_{2}$ has an overall positive charge in the experimental conditions, although some areas are still able to bind cations on the adsorbent surface. The overall positive surface charge of $\mathrm{H}-\mathrm{TiO}_{2}$ or $\mathrm{Na}-\mathrm{TiO}_{2}$ becomes a Coulomb barrier for the adsorption of relatively large, positively charged ions of divalent strontium and trivalent yttrium. Therefore, strontium and yttrium ions were not adsorbed by these adsorbents in the $0.32 \mathrm{M} \quad \mathrm{HNO}_{3}$ medium. It should be noted, that at $\mathrm{pH}$ values closer to a

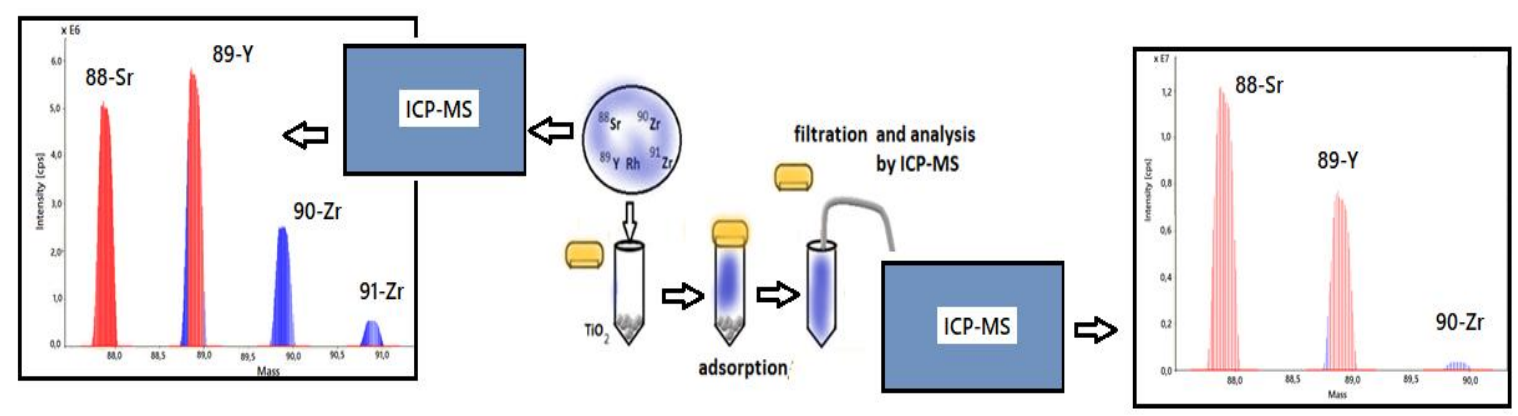

Fig. 7. Scheme of the experiment of separation of strontium, yttrium and zirconium ions and subsequent ICP-MS analysis.

Table 5

Results of selective adsorption of zirconium ions by $\mathrm{H}-\mathrm{TiO}_{2}$ and $\mathrm{Na}-\mathrm{TiO}_{2}$

\begin{tabular}{|c|c|c|c|c|c|c|c|c|}
\hline \multicolumn{2}{|c|}{$\begin{array}{c}\text { C initial } \\
90-\mathrm{Zr} \\
(\text { Standard 2) }\end{array}$} & \multirow{2}{*}{$\begin{array}{l}\text { Adsor- } \\
\text { bent }\end{array}$} & \multirow{2}{*}{$\begin{array}{l}\text { Intensity } \\
\text { [cps] } \\
\text { After } \\
\text { adsorption }\end{array}$} & \multicolumn{2}{|c|}{$\begin{array}{c}\text { Adsorption } \\
90-\mathrm{Zr}\end{array}$} & \multirow{2}{*}{$\begin{array}{c}\text { C residual, } \\
90-\mathrm{Zr} \\
\mathrm{ng}\end{array}$} & $\begin{array}{c}\text { Uncertaintie } \\
\text { s } \\
89 \mathrm{Y} 1 \mathrm{H}\end{array}$ & \multirow{2}{*}{$\begin{array}{c}\alpha \\
\mathrm{Sr}, \mathrm{Zr}\end{array}$} \\
\hline $\begin{array}{c}\text { Inten-sity } \\
\text { [cps] }\end{array}$ & ng & & & ng & $\%$ & & \multirow{3}{*}{1210} & \\
\hline 1057427 & 5.094 & $\mathrm{H}-\mathrm{TiO}_{2}$ & $156695 \pm 554$ & 4.3392 & 85.18 & 0.7548 & & 25.63 \\
\hline 2229000 & 6.46 & $\mathrm{Na}-\mathrm{TiO}_{2}$ & $146506 \pm 768$ & 6.0355 & 93.42 & 0.4245 & & 27.42 \\
\hline
\end{tabular}

Amounts of ${ }^{88} \mathrm{Sr},{ }^{89} \mathrm{Y}$ and ${ }^{103} \mathrm{Rh}$ before and after adsorption

Table 5 (a)

\begin{tabular}{|c|c|c|c|c|c|c|}
\hline \multirow{2}{*}{ Isotop } & \multicolumn{2}{|c|}{$\begin{array}{c}\mathrm{C}_{\text {initial }} \\
(\text { Standard } 2)\end{array}$} & \multirow{2}{*}{ Adsorbent } & \multirow{2}{*}{$\begin{array}{l}\text { Intensity } \\
\text { [cps] } \\
\text { After } \\
\text { adsorption }\end{array}$} & \multirow{2}{*}{$\begin{array}{c}\text { Intensity } \\
\text { [cps] } \\
\text { Standard } 3\end{array}$} & \multirow{2}{*}{$\begin{array}{c}\text { Uncertainties } \\
{ }^{90} \mathrm{Zr} \\
\text { Standard } 3 \\
\text { [cps] }\end{array}$} \\
\hline & $\begin{array}{c}\text { Intensity } \\
\text { [cps] }\end{array}$ & ng & & & & \\
\hline $88-\mathrm{Sr}$ & 2101905 & 9.9 & $\mathrm{H}-\mathrm{TiO}_{2}$ & 4017586 & 510471 & \multirow{5}{*}{14588} \\
\hline $89-Y$ & 2431139 & 10 & $\mathrm{H}-\mathrm{TiO}_{2}$ & 3179047 & 9245 & \\
\hline $88-\mathrm{Sr}$ & 10413000 & 14.5 & $\mathrm{Na}-\mathrm{TiO}_{2}$ & 10027000 & 14588 & \\
\hline $89-Y$ & 5715000 & 12.5 & $\mathrm{Na}-\mathrm{TiO}_{2}$ & 4663000 & 1768.8 & \\
\hline 103-Rh & 516693 & 3 & $\mathrm{H}-\mathrm{TiO}_{2}\left(\mathrm{Na}-\mathrm{TiO}_{2}\right)$ & 448009 & - & \\
\hline
\end{tabular}




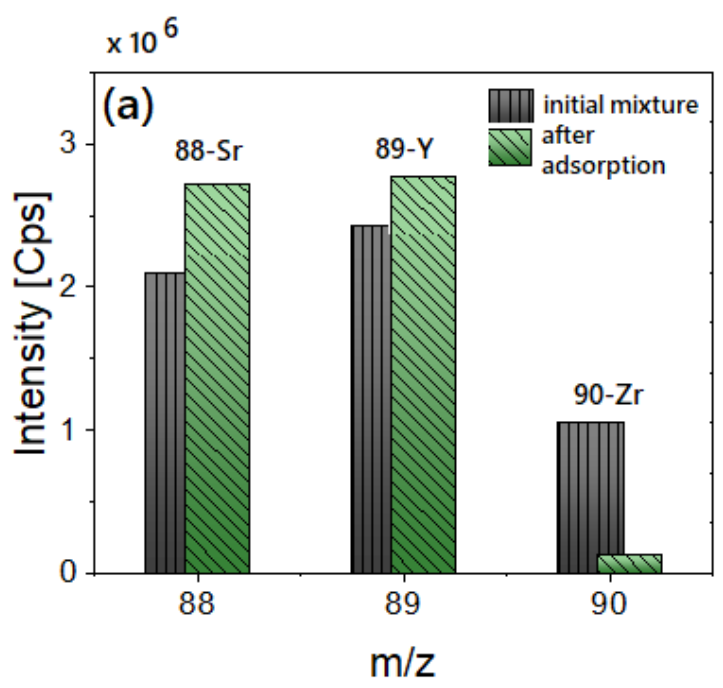

Fig. 8 (a). ICP-MS spectra of a solution containing about $10 \mathrm{ng}$ of strontium, yttrium, and zirconium ions, before and after adsorption by $\mathrm{H}-\mathrm{TiO}_{2}$.

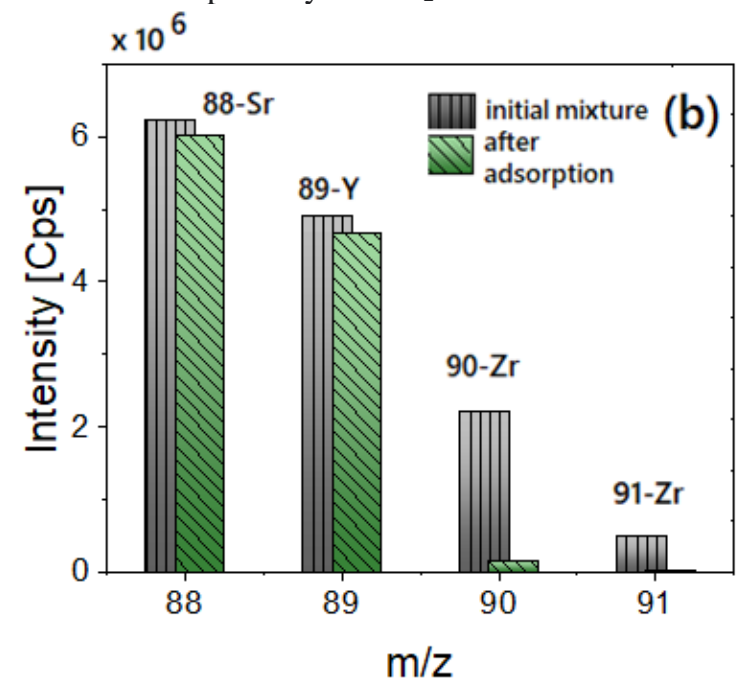

Fig. 8 (b). ICP-MS spectra of a solution containing about $10 \mathrm{ng}$ of strontium, yttrium, and zirconium ions, before and after adsorption by $\mathrm{Na}-\mathrm{TiO}_{2}$.

neutral or alkaline environment, the adsorption of strontium ions by these adsorbents is extremely intense [914]. Ionic radius of $\mathrm{Zr}^{4+}$ is smaller than the corresponding value of $\mathrm{Sr}^{2+}$ or $\mathrm{Y}^{3+}\left(0.84 \AA\right.$ compared to $1.02 \AA$ for $\mathrm{Y}^{3+}$ and $1.26 \AA$ for $\mathrm{Sr}^{2+}$ ions) [26]. Zirconium loses its hydrate shell under such acidity of the solution. This fact allows zirconium ions to neglect electrostatic repulsion and interact with residual cation-bonding adsorption cites of the adsorbents. On the other hand, the mobility of zirconium ions is much lower than the mobility of strontium ions [25]. Therefore, after approaching the surface of $\mathrm{TiO}_{2}$, zirconium generally remains in the adsorbed state.

The obtained results are promising for the separation of ${ }^{90} \mathrm{Sr}$ and ${ }^{90} \mathrm{Zr}$ isotopes. The absence of adsorption of strontium and yttrium ions under such extreme solution acidity indicates that zirconium ions can be selectively adsorbed even with an excess of cations of alkaline earth elements and elements of the YRE group. The resistance of $\mathrm{TiO}_{2}$ to the acidic media allows direct one-stage separation of zirconium ions without additional procedures for the separation of alkaline earth elements and lanthanides, which can shift the initial ratio of ${ }^{90} \mathrm{Sr} /{ }^{90} \mathrm{Zr}$ [27-29]. This fact is extremely valuable for nuclear forensics or the determination of ${ }^{90} \mathrm{Sr}$ in low activity background samples.

\section{Conclusion}

The adsorption of zirconium ions by titanium dioxide has been studied. The dependence of this process on the agitation time, the equilibrium concentration of the zirconium ions, and the acidity of the solution have been established.

The kinetics of zirconium ions adsorption by $\mathrm{H}-\mathrm{TiO}_{2}$ and $\mathrm{Na}-\mathrm{TiO}_{2}$ is stepwise and fitting well with the diffusion kinetic model.

Experimental maximum values of adsorption of zirconium ions by the studied adsorbents are $61.4 \mathrm{mg} \cdot \mathrm{g}^{-1}$ for $\mathrm{H}-\mathrm{TiO}_{2}$ and $109.5 \mathrm{mg} \cdot \mathrm{g}^{-1}$ for $\mathrm{Na}-\mathrm{TiO}_{2}$. These values are in good agreement with the calculated values of the maximum adsorption according to Langmuir's theory.

Separation of strontium and zirconium ions was performed. The residual solution was analyzed by ICPMS. It was shown that the investigated adsorbents selectively adsorb zirconium ions from the mixture with strontium and yttrium ions in the range of solution $\mathrm{pH}=$ 0 - 1 . The percentage of maximum extraction of zirconium ions is $86.61 \%$ for $\mathrm{H}-\mathrm{TiO}_{2}$ and $94.11 \%$ for $\mathrm{Na}-\mathrm{TiO}_{2}$. This fact is extremely valuable for nuclear forensics or the determination of ${ }^{90} \mathrm{Sr}$ in low activity background samples.

\section{Funding}

This work was supported by a research grant in Nuclear Forensics. STCU [Project 9906].

Vasylyeva H. - Ph.D., Associated professor, Department of Theoretical Physics;

Mironyuk I. - Professor, Dr.Sci., Head of Department of Chemistry;

Mykytyn I. - PhD., Associated professor of Department of Chemistry;

Strilchuk M. - PhD., Senior researcher of Nuclear forensics laboratory;

Maliuk I. - PhD., Head of Nuclear forensics laboratory; Tryshyn V. - PhD., Deputy Director of the Institute for Nuclear Research.

Savka Kh. - Ph.D. student of the Department of Chemistry. 
[1] I.F. Mironyuk, I.M. Mykytyn, O.Ye. Kaglyan, D.I. Gudkov, Nucl. Phys. At. Energy 21(4) 347 (2020); https://doi.org/10.15407/jnpae2020.04.347.

[2] Public health statement: strontium. https://www.atsdr.cdc.gov/ ToxProfles/tp159-c1-b.pdf. Accessed 1 Feb (2019).

[3] Kevin John Swearingen, Nathalie A. Wall, Journal of Radioanalytical and Nuclear Chemistry 320, 71 (2019); https://doi.org/10.1007/s10967-019-06444-6.

[4] N. Kavasi, S.K. Sahoo, H. Arae, T. Aono, Z. Palacz, Nature Scientific Reports 9, 16532 (2019); https://doi.org/10.1038/s41598-019-52890-3.

[5] Scott C. Wilschefski, Matthew R Baxter, Clin. I. Biochem Rev 40(3) 115 (2019); https:/doi.org/10.33176/AACB-19-00024.

[6] G. Favre, R. Brennetot, et al., International Journal of Mass Spectrometry 265(1) 15 (2007); https://doi.org/10.1016/j.ijms.2007.04.012.

[7] Zattoni Ana Paula, Separation and Analysis of Sr-90 and Zr-90 for Nuclear Forensic Applications. (Laval University, Quebec, Canada, 2015); 31654.pdf (ulaval.ca) http://hdl.handle.net/20.500.11794/26052.

[8] Hendee William R., Ritenour E. Russel, Medical Imaging Physics, $4^{\text {th }}$ edition. (A John Wiley \&Sons inc. publication, New York, 353, 2002). ISBN: 9780471221159; https://www.doi.org.10.1002/0471221155.

[9] I. Mironyuk et al., Journal of Molecular Liquids, 282, 587 (2019); https://doi:10.1016/J.MOLLIQ.2019.03.026.

[10] I. Mironyuk et al., Journal of Environmental Chemical Engineering 7(6) 103430 (2019); https://www.doi.org/10.1016/j.jece.2019.103430.

[11] I. Mironyuk et al., Journal of Molecular Liquids, 285, 742 (2019); https://www.doi.org/10.1016/j.molliq.2019.04.111.

[12] I. Mironyuk, I. Mykytyn, H. Vasylyeva, Kh. Savka, Journal of Molecular Liquids 316(10) 113840 (2020); https://www.doi.org/10.1016/j.molliq.2020.113840.

[13] I.F. Mironyuk, H.V. Vasylyeva, Sorption removal of $\mathrm{Sr}^{2+}$ and $\mathrm{Y}^{3+}$ ions from aqueous solutions by a $\mathrm{TiO}_{2}-$ based $^{2}$ sorbent. RAD Conf. Proc. 3 (2018). P.15; https://doi.org/10.21175/RadProc.2018.04.

[14] H. Vasylyeva, I. Mironyuk, I. Mykytyn, Kh. Savka, Applied Radiation and Isotopes 109473 (2020); https://doi.org/10.1016/j.apradiso.2020.109473.

[15] H. Vasylyeva, I. Mironyuk, I. Mykytyn, Chemistry, physics, and technology of surface 10(4) 446 (2019); https://www.doi.org:10.15407/hftp10.04.446.

[16] G. Schwarzenbach, H. Flaschka, Complexometric titrations. Translated [from the German] and rev. in collaboration with the authors by H.M.N.H. (Irving, London, Methuen, P. 490 (1969). ISBN: 0416192904 9780416192902.

[17] Arthur W. Adamson, Physical chemistry of surfaces ( $3^{\text {rd }}$ edition) (Wiley-Interscience, New York, 698, 1976); https://doi.org/10.1002/pol.1977.130151014.

[18] W. Plazinski, W. Rudzinski, A. Plazinska, Advances in Colloid and Interface Science 152(1-2), 2 (2009); https://doi.org/10.1016/j.cis.2009.07.009.

[19] F.-Ch. Wu, R.-L. Tseng, R.-Sh. Juang, Chemical Engineering Journal 150(2-3), 366 (2009); https://doi.org/10.1016/j.cej.2009.01.014.

[20] H.N. Tran, S-J. You, A. Hosseini-Bandegharaei, H-P. Chao, et al., Water Res. 120, 88 (2017).

[21] Fatin Izzaidah Anuar, Tony Hadibarata, Muhammad Syafrudin, Zahra Fona, Biointerface Research in Applied Chemistry 10(1), 4774 (2020); ISSN 2069-5837; https://doi.org/10.33263/BRIAC101.774779.

[22] Shivashanggeeta Kanthasamy, Tony Hadibarata et al., Biointerface Research in Applied Chemistry 10(1), 4706 (2020); ISSN 2069-5837; https://doi.org/10.33263/BRIAC101.706713.

[23] H. Vasylyeva, I. Mironyuk, M. Strilchuk, et al., Biointerface Research in Applied Chemistry 11(5), 13421 (2021); http://dx.doi.org/10.33263/BRIAC115.1342113431.

[24] Atlas of Eh-pH diagrams, (2005). Intercomparison of thermodynamic databases Geological Survey of Japan Open-File Report No.419.

[25] V.E. Staryk et al., Radiochemistry,6(4), 468 (1964). (in Russian).

[26] K.M. Mackay, R.A. Mackay, W. Henderson, Introduction to modern inorganic chemistry $5^{\text {th }}$ edition (Blackie Academic and professional, and imprint of Chapman and Hall, 2-6 Boundary Row, London SE1 8NH, UK, (1996); ISBN 0751403733.

[27] McLain Derek R., Amato Victoria, Sudowe Ralf, J Radioanal. Nucl. Chem. 314(3) 15 (2018); https://www.doi.org:10.1007/s10967-017-5599-x.

[28] Zsolt Varga, Adrian Nicholl, Maria Wallenius, Klaus Mayer, J. Radioanal. Nucl. Chem. 307, 1919 (2015); https://www.doi.org.10.1007/s10967-015-4418-5.

[29] J.L. Steeb, D.G. Graczyk, Y. Tsai, et al., J. Anal. At. Spectrom. 28, 1493 (2013); https://pubs.rsc.org/en/journals/journal/ja. 


\title{
Г. Васильєва ${ }^{1}$, I. Миронюк², І. Микитин ${ }^{2}$, М. Стрільчук $^{3}$, I. Малюк ${ }^{3}$, В. Тришин ${ }^{3}$, Х. Савка ${ }^{2}$
}

\section{Використання діоксиду титану для адсорбції йонів цирконію та виділення їх із багатокомпонентної суміші}

\author{
${ }^{l}$ Ужгородський національний університет, Ужсород, Україна, h.v.vasylyeva@ hotmail.com \\ ${ }^{2}$ Прикарпатський національний університет ім. В.Стефаника, Івано-Франківськ, Україна, тугіf555@ gmail.com \\ ${ }^{3}$ Лабораторія ядерної криміналістики, Iнститут ядерних досліджень, HАH, Київ, Україна, myst@ kinr.kiev.ua
}

Дана робота присв'ячена дослідженням адсорбції йонів цирконію мезопористим діоксидом титану та діоксидом титану із натрованою поверхнею. Експериментально визначені величини максимальної адсорбції йонів цирконію складають 64 мг/г та 109,5 мг/г відповідно для адсорбентів $\mathrm{H}-\mathrm{TiO}_{2} \mathrm{i} \mathrm{Na}_{\mathrm{N}} \mathrm{TiO}_{2}$. Процес адсорбції залежить від тривалості взаємодії, рівноважної концентрації йонів цирконію та кислотності розчину. Кінетика адсорбції найкраще може бути описана дифузійною кінетичною моделлю і вказує на ступінчастий характер адсорбції йонів цирконію обома адсорбентами. Рівноважну адсорбцію йонів цирконію адсорбентами $\mathrm{H}-\mathrm{TiO}_{2}$ i $\mathrm{Na}_{-} \mathrm{TiO}_{2}$ найкраще описує теорія Ленгмюра. Із застосуванням масспектрометрії з індуктивно зв'язаною плазмою, показано, що досліджені адсорбенти селективно поглинають йони цирконію із суміші із йонами стронцію та ітрію при значенні кислотності розчину $\mathrm{pH}=0$ - 1. Відсоток вилученого цирконію із суміші складає 86,61 \% для $\mathrm{H}_{-} \mathrm{TiO}_{2}$ i 94,11 \% для $\mathrm{Na}^{-\mathrm{TiO}_{2}}$. Цей факт є дуже корисним для ядерної криміналістики а також при визначенні кількості ${ }^{90} \mathrm{Sr}$ у низькофонових зразках навколишнього середовища.

Ключові слова: мезопористий $\mathrm{TiO}_{2}$, йони цирконію, адсорбція, розділення, ICP-MS. 